\title{
Bahasa dan kognisi Studi korelasional tentang pemahaman teks ekspositori dan berpikir deduktif dan induktif pada siswa SMA
}

\author{
RATIH RAMELAN
}

\begin{abstract}
This correlational study is to show the role of deductive and inductive reasoning abilities as aspects of cognitive development on expository text comprehension among high school students who already have a capacity to think in conceptual and hyphotetical ways and to examine how they correlate and influence the text comprehension process. This study has broaden our knowledge of language and thinking, as it is different from other previous studies that focused on comprehension process among elementary students, narrative, reading strategies, and comprehension difficulties. It is found that deductive reasoning is more significantly correlated to expository text comprehension than inductive reasoning. There is other significant differences between natural sciences and social sciences students in expository text comprehension and deductive reasoning, where the average scores of the natural sciences students on both variables are higher than those of social sciences students. It shows that the ability to analisesyntesise, to relate some basic elements of a text, and to draw a conclusion or main idea of the text support the process of expository text comprehension, and can be taught and developed by learning process. Meanwhile, inductive reasoning ability is significantly different between male and female students, and it does not correlate to expository text comprehension.
\end{abstract}

KEYWORDS

pemahaman teks (text comprehension), berpikir deduktif (deductive reasoning), dan berpikir induktif (inductive reasoning).

RATIH RINI HASTUTI RAMELAN adalah staf pegawai bidang kehumasan organisasi regional Sekretariat ASEAN, telah meraih gelar Master Humaniora dari Fakultas Ilmu Pengetahuan Budaya, Universitas Indonesia pada tahun 2007 di bidang Linguistik, dan menaruh minat mendalam pada kajian Psikolinguistik. Gelar sarjana psikologi diraih dari Fakultas Psikologi, Universitas Indonesia pada tahun 1989 dengan kajian utama pada psikologi pendidikan. Ia aktif paruh waktu sebagai penerjemah buku (dari bahasa Inggris ke bahasa Indonesia) dengan minat pada psikologi, sastra, sejarah, pengembangan kepribadian, dan ilmu pengetahuan alam. E-mail: ratihramelan@yahoo.com. 
Pemahaman teks merupakan topik yang luas dikaji terutama dalam lapangan psikologi, pendidikan, dan bahasa. Aktivitas kompleks membaca dan memahami teks meliputi proses interaktif antara aspek linguistik dan psikologis. Just dan Carpenter (1987: 4, 10) dan Grabe dan Stoller (2002: 20-25) menjelaskan bahwa kemampuan membaca terkait dengan karakter linguistis teks yang terlebih dahulu harus dikuasai (lower-level process), seperti pengenalan kata, pemenggalan kalimat, atau pembentukan proposisi semantis. Sementara itu, pada tingkat yang lebih tinggi (higher-level process), kemampuan membaca menggambarkan proses pemahaman yang berkait dengan keterampilan menarik simpulan atau membuat inferensi, menangkap esensi situasional teks, atau penggunaan latar belakang pengetahuan. Kedua tingkatan ini terjadi secara simultan dan terkait dengan karateristik teks dan kapasitas individu. Sebagai contoh, ketika seseorang membaca sebuah berita utama di sebuah surat kabar, maka struktur dan koherensi teks dalam berita itu akan berinteraksi dengan pengetahuan, kemampuan analisis, dan strategi dan mekanisme kognitif pembaca, sehingga memengaruhi hasil akhir berupa pemahaman tentang berita itu. Dasar dari interaksi keduanya adalah pengoordinasian sejumlah gagasan dalam teks untuk menggambarkan gagasan utama dan gagasan pendukung yang membentuk representasi makna teks.

Sebagai hasil akhir membaca, pemahaman teks terlihat dalam bentuk struktur makro atau intisari makna teks secara keseluruhan yang merupakan hasil dari proses inferensial yang dilakukan pembaca atau disebut juga model situasi (Kintsch dalam Solso 1991; Jay 2003). Keadaan yang menggambarkan hal itu tampak misalnya pada seseorang yang sedang menceritakan kembali sebuah artikel, cerita pendek, atau buku yang telah dibacanya. Kita dapat menangkap bahwa yang diceritakan kembali adalah esensi makna dan situasi keseluruhan teks. Boleh jadi ia menggunakan kata-katanya sendiri yang tidak sama dengan yang ada pada teks, tetapi tidak mengubah arti. Artinya, kemampuan membaca merupakan proses mental yang lebih tinggi yang menunjukkan kemampuan menghasilkan esensi makna menyeluruh teks. Mampu membaca teks menunjukkan pemahaman pembaca tentang teks.

Sementara itu, berkait dengan kegiatan belajar mengajar dalam dunia pendidikan khususnya pendidikan lanjutan atas, membaca dan pemahaman bacaan adalah salah satu keterampilan esensial yang harus dimiliki siswa. Sesuai dengan alur teori perkembangan kognitif Piaget (McShane 1991), dengan bertambahnya usia individu, perkembangan kognitifnya pun berkembang menuju ke taraf formal operasional yang karakteristiknya adalah mampu berpikir abstrak, logis, dan hipotetis. Jadi, semakin tinggi tingkat pendidikan, semakin tinggi karakter kapasitas mental yang dimiliki siswa, semakin rumit bahan bacaan yang harus dipahami dan semakin memerlukan kemampuan pemahaman teks pada tingkat yang lebih tinggi.

Dari observasi terhadap sejumlah siswa sekolah menengah atas dan diri sendiri dalam tugas membaca dan memahami buku teks sekolah yang umumnya bersifat ekspositoris, dapat disimpulkan bahwa pemahaman teks dan penarikan gagasan utama teks bukanlah tugas yang mudah dan sederhana, 
bahkan kerap menjadi permasalahan serius yang dapat memengaruhi prestasi akademis. Analisis terhadap sejumlah cara untuk mengukur berapa jauh suatu teks ekspositori dipahami, seperti menjawab pertanyaan konseptual, menceritakan kembali, membuat pertanyaan atau poin penting tentang teks, menunjukkan bahwa proses pemahaman membaca melibatkan proses pikir yang rumit. Jadi, kemampuan memahami teks ekspositori merupakan hal penting bagi siswa sekolah menengah atas yang kelak akan melanjutkan pendidikan di perguruan tinggi yang tentunya menuntut taraf kemampuan intelektual tinggi, antara lain kemampuan berpikir abstraktif atau konseptual, yang termanifestasi dalam bahasa lisan atau tulis. Teks ekspositori memiliki karakteristik, struktur dan isi yang bersifat konseptual, deskriptif, mengandung hubungan sebab-akibat, dan sekuen dan menuntut pembacanya untuk memiliki kapasitas berpikir yang memadai untuk dapat memahami teks tersebut.

Berangkat dari pemikiran itu maka adalah penting untuk mengkaji lebih dalam tentang bagaimana korelasi antara pemahaman teks ekspositori, berpikir deduktif, dan berpikir induktif pada siswa sekolah menengah atas dan berapa jauh berpikir deduktif dan berpikir induktif berperan dalam pemahaman teks ekspositori pada siswa tersebut. Dengan mengetahui bagaimana sifat korelasi dan peran variabel berpikir deduktif dan berpikir induktif dalam pemahaman teks, maka kegiatan membaca dan pemahaman teks dapat lebih dipahami sebagai aktivitas yang penting yang diharapkan dapat menjawab permasalahan dan kesulitan yang timbul dalam proses pemahaman teks ekspositoris dan menjadi pijakan dalam aktivitas belajar mengajar.

\section{TEORI TENTANG PEMAHAMAN TEKS EKSPOSITORI DAN BERPIKIR DEDUKTIF-INDUKTIF}

Pemahaman terentang dalam dimensi intelektualitas yang menyangkut pengertian dan pengetahuan tentang fakta. Parson, Hinson, dan SardoBrown (2001) menjelaskan bahwa dalam domain kognitif taksonomi Bloom, pemahaman adalah keterampilan intelektual yang menunjukkan pengetahuan tentang apa yang "dikatakan" oleh bentuk verbal, gambar, atau simbol. Pemahaman memperlihatkan adanya pengertian tentang fakta dan gagasan dengan cara mengorganisasi, membandingkan, menerjemahkan, menafsirkan, memberikan deskripsi, dan menyatakan ide atau gagasan utama teks. Di dalamnya ada proses memahami informasi, menangkap makna, menerjemahkan pengetahuan ke dalam konteks baru, menafsirkan fakta, menarik hubungan sebab-akibat dan konsekuensi. Pemahaman bersifat abstrak dan ada pada wilayah psikologi karena berhubungan dengan fungsi kognitif dalam memahami informasi, menangkap esensi dan makna, dan menarik hubungan kausal.

Dalam kaitannya dengan teks, studi tentang pemahaman teks umumnya bertujuan untuk memahami faktor apa yang ada pada teks serta proses apa yang terjadi dalam diri pembaca yang memengaruhi pemahaman. Kajian 
tentang faktor karakteristik teks, antara lain, berkaitan dengan struktur, genre, panjang dan pendeknya teks. Teks ekspositori, sebagai salah satu genre teks, menyediakan tantangan bagi pembaca karena strukturnya yang berbeda dengan teks naratif. Singer dan O'Connell (2006) mengemukakan bahwa teks ekspositori berisi kategori dan struktur abstrak, seperti daftar, hierarki, sekuen, kategorisasi, dan sebab-akibat; sementara teks naratif berisi tokoh dan kejadian.

Model pemahaman teks yang kerap dijadikan rujukan adalah model Construction Integration Kintsch (Solso 1991; Stevenson 1993; Jay 2003). Dalam model ini, pemahaman teks direpresentasikan dalam tiga tingkatan, yaitu (i) representasi permukaan kata atau kalimat (surface representation) yang ditunjukkan oleh representasi kata dan frasa yang pasti atau sama persis; (ii) tingkat makna teks (textbase) di mana isi semantis teks direpresentasikan tidak dengan kata orisinalnya tetapi dengan kata lain yang sama maknanya atau disebut juga representasi proposisional; dan (iii) model situasional (situational model) yang merupakan tingkat pemahaman tertinggi dalam bentuk representasi mental tentang situasi teks yang didasarkan pada penalaran. Dalam taraf ini, pemahaman diwujudkan dengan kemampuan menarik gagasan utama teks, yang mengindikasikan kemampuan pembaca dalam membentuk representasi mental menyeluruh tentang teks. Gagasan utama teks itu sendiri, antara lain, terekspresikan melalui judul teks. Mampu dengan baik mengidentifikasikan gagasan utama merupakan indikasi yang jelas bahwa pembaca telah membentuk representasi mental yang koheren tentang teks yang dibacanya, yang diingatnya, yang dipetiknya pelajaran dari dalamnya (Van den Broek et al. 2003). Dengan demikian, parameter pemahaman teks ekspositori dapat terlihat melalui kemampuan menangkap gagasan utama teks.

Di sisi lain, selain strategi yang diterapkan, latar belakang pengetahuan dan minat pembaca, maka mekanisme kognitif merupakan aspek dalam faktor individu atau pembaca yang terus dikaji. Secara lebih spesifik, kemampuan kognitif menekankan bagaimana kapasitas mental manusia bekerja dalam menerima informasi dari lingkungan melalui alat indra, memprosesnya, mengenali apa yang dipersepsi, membandingkannya dengan data yang telah dimiliki, mengklasifikasikannya, dan menyimpannya dalam ingatan serta menggunakannya dalam merespons rangsangan (Lobner 2002). Secara sederhana dapat dikatakan bahwa kemampuan kognitif adalah aktivitas mental psikologis berupa kemampuan berpikir atau menalar. Artinya, bagaimana pembaca memahami teks ekspositori yang abstraktif tentunya dipengaruhi oleh fungsi kognitif yang bekerja.

Eysenck (1994) dan Thomson (2000) menjelaskan bahwa berpikir atau menalar adalah proses yang bersandar pada aturan dalam memutuskan secara logis apa yang diyakini dan proses penarikan simpulan dari sejumlah fakta, bukti, dan data. Aktivitas dasar menalar adalah menarik simpulan atau konklusi dan mengevaluasi bukti dan merupakan hal esensial yang menunjukkan kemampuan individu untuk melakukan hal yang melampaui 
apa yang tersedia dalam informasi yang ada.

Dua tipe menalar atau berpikir yang dijelaskan Eysenck (1994), Bluedorn (1995), dan Copi dan Burgess-Jackson (1996), adalah berpikir deduktif dan induktif. Berpikir deduktif dan induktif adalah salah satu komponen kognitif dan merupakan proses mental dalam taraf yang lebih tinggi yang dapat menjelaskan tentang bagaimana manusia menalar, menganalisis-sintesis, memecahkan masalah, membuat generalisasi dan menarik simpulan dari apa yang dipersepsi, yang didasarkan pada premis atau gejala yang ada, baik berupa peristiwa, pernyataan bahasa tulis dan lisan, atau citra. Dari apa yang dikemukakan oleh Hurley (2000) dan Hayon (2005), dapat disimpulkan bahwa perbedaan fundamental antara keduanya terletak pada hubungan antara premis dan konklusinya. Pada deduktif hubungannya harus kuat dan konklusinya mengikuti premis dengan keharusan (necessity); pada induktif hubungannya tidak kaku dan konklusinya mengikuti premis dengan kemungkinan (probability).

Secara lebih spesifik dapat dijelaskan bahwa argumen berpikir deduktif dapat dibuktikan kebenarannya. Kebenaran konklusi dalam argumen deduktif bergantung pada dua hal, yaitu kesahihan bentuk argumen berdasarkan prinsip dan hukumnya; dan kebenaran isi premisnya berdasarkan realitas. Sebuah argumen deduktif tetap dapat dikatakan sahih berdasarkan bentuknya, meskipun isinya tidak sesuai dengan realitas yang ada; atau isi argumen deduktif benar menurut realitas meskipun secara bentuk ia tidak sahih. Dua tipe argumen deduktif adalah silogisme kategoris dan silogisme hipotetis. Silogisme kategoris adalah argumen yang pasti terdiri atas dua premis dan satu konklusi, dengan setiap pernyataannya dimulai dengan kata semua, tidak ada, dan beberapa atau sebagian, dan berisi tiga bagian yang masing-masing hanya boleh muncul dalam dua proposisi silogisme.

Premis 1: $\quad$ Semua atlet adalah orang yang sehat jiwa raga.

Premis 2: $\quad$ Beberapa pelajar adalah atlet.

Konklusi: Jadi, beberapa pelajar adalah orang yang sehat jiwa raga.

Silogisme hipotetis adalah silogisme yang memiliki pernyataan kondisional atau bersyarat pada premisnya. Ada tiga jenis silogisme hipotetis, yaitu silogisme kondisional yang mengandung anteseden (syarat) dan konsekuensi; silogisme disjungtif berupa pernyataan yang menawarkan dua kemungkinan; dan silogisme konjungtif yang bertumpu pada kebenaran proposisi kontraris. Kesahihan dan ketidaksahihan setiap bentuk silogisme tersebut diukur dengan hukum dan prinsip dasar berpikir deduktif, menyangkut pengakuan dan pengingkaran pada premisnya. Beberapa contoh silogisme hipotetis terlihat di bawah ini: 
(i) Silogisme hipotetis:

Bila hari tidak hujan, Ani akan pergi ke bandara.

Hari hujan.

Oleh karena itu, Ani tidak pergi ke bandara.

(ii) Silogisme disjungtif:

A atau B

Arif menulis prosa atau puisi

Ternyata bukan A

Maka B

Ternyata Arif tidak menulis prosa

Maka, Arif menulis puisi

(iii) Silogisme konjungtif:

A tidak mungkin Arif tidak mungkin sekaligus menulis prosa dan puisi

sekaligus B dan C

Ternyata A adalah B Ternyata Arif menulis prosa

Maka, A bukan C Maka, Arif tidak menulis puisi

Jadi, dari penjelasan tentang berpikir deduktif yang termanifestasi dalam bentuk silogisme kategoris dan silogisme hipotetis (kondisional, disjungtif, dan konjungtif) dapat disimpulkan bahwa berpikir deduktif adalah cara berpikir logis yang mengikuti serangkaian aturan. Di dalamnya berlangsung aktivitas berpikir analisis dan sintesis terhadap kondisi atau situasi yang ada.

Di sisi lain, berpikir induktif bergerak dari premis spesifik ke konklusi umum atau generalisasi. Observasi dan pengalaman digunakan untuk mendukung generalisasi. Premisnya tidak menjadi dasar untuk kebenaran konklusi, tetapi memberikan sejumlah dukungan untuk konklusinya. Konklusi induktif jauh melampaui apa yang ada pada premisnya.

Hitler adalah diktator dan bengis.

Stalin adalah diktator dan bengis.

Castro adalah diktator.

Oleh karena itu, Castro sangat boleh jadi juga bengis.

Sebagian besar berpikir atau menalar induktif tidak didasarkan pada bukti yang menyeluruh sehingga bentuk ini tidaklah lengkap. Setiap argumen induktif tidak dapat dikatakan sahih atau tidak sahih, tetapi lebih baik atau kurang baik, bergantung pada berapa tinggi derajat probabilitasnya (kebolehjadian) yang diberikan premis pada simpulannya. Semakin tinggi probabilitas simpulannya semakin baik argumen induktif yang bersangkutan, begitu pula sebaliknya, dan simpulannya tidak mungkin mengandung kepastian mutlak. Konklusi induktif tidak akan pernah terbukti benar kecuali bila meneliti semua premis khususnya.

Serupa dengan pemahaman teks ekspositori, kemampuan berpikir deduktif dan induktif adalah perilaku mental individu yang dapat diukur, didasarkan pada sejumlah hukum, prinsip dasar, kriteria kesahihan bentuk argumen, dan 
pola spesifik berkenaan dengan berpikir deduktif dan induktif.

Di samping itu, perbedaan individu (individual differences) juga menjadi faktor nonpenelitian yang perlu dipertimbangkan karena sangat boleh jadi turut menyumbang pada berapa jauh kemampuan berpikir deduktif dan berpikir induktif berkorelasi dan selanjutnya berkait dengan pemahaman teks ekspositori. Beberapa kajian tentang perbedaan individual dalam kemampuan berpikir deduktif dan induktif berkait dengan gender telah dilakukan. Brandon (1989) mengemukakan bahwa tidak ada perbedaan dalam kemampuan berpikir deduktif pada laki-laki dan perempuan. Di sisi lain, Zago et al. (2007) dan Schaie (2007) menjelaskan bahwa perempuan tampil lebih baik dalam tugas verbal, ingatan, kefasihan dalam kata, dan penalaran induktif, sedangkan laki-laki lebih berprestasi dalam orientasi spasial dan angka.

Dalam hubungannya dengan bahasa, Falmagne dan Gonsalves (1995) mengemukakan bahwa dewasa ini sejumlah teori telah mengakui adanya kaitan yang signifikan antara proses berpikir deduktif dan linguistik. Inferensi deduktif merupakan satu komponen dalam aktivitas kognitif dan oleh karena itu hubungannya dengan proses linguistik dan nonlinguistik menjadi penting. Selain itu, Thomson (2000) menjelaskan bahwa penalaran tentu saja terungkap dalam bahasa tetapi tidak semua komunikasi dalam bahasa melibatkan penalaran. Penalaran berjalan paralel dengan pemahaman teks bahasa dalam tingkat model situasi, yaitu dalam hal menarik konklusi yang melampaui apa yang ternyatakan secara eksplisit.

\section{METODE}

Penelitian ini bersifat kuantitatif untuk mengukur seberapa signifikan korelasi antara skor kelompok siswa dalam pemahaman teks ekspositori dan skor kelompok siswa dalam berpikir deduktif dan berpikir induktif.

\section{VARIABEL PENELITIAN}

Variabel yang terlibat dalam penelitian ini adalah (i) variabel bebas (independent variable), yaitu teks ekspositori tipe A dengan gagasan utama di awal teks dan teks ekspositori tipe B dengan gagasan utama di akhir teks; (ii) variabel tidak bebas (dependent variable) adalah pemahaman teks; (iii) variable berpikir deduktif dan induktif untuk mengelompokkan kemampuan berpikir deduktif dan induktif subjek penelitian.

\section{INSTRUMEN PENELITIAN DAN SKOR}

Pembuatan alat ukur tes atau kuesioner didasarkan pada paduan pembuatan tes yang mencakupi struktur atau bentuk tes dan isi tes (Kline 1986; Hughes 1989; Weir 1993; Richter dan Naumann 2000). Instrumen penelitian ini berupa kuesioner yang mengukur variabel pemahaman teks ekspositori dengan gagasan utama di awal teks, di akhir teks, kemampuan berpikir deduktif, induktif, dan variabel nonpenelitian lain, seperti jenis kelamin dan jurusan sekolah. Bentuk kuesioner adalah pilihan ganda yang terdiri atas pertanyaan dan pilihan jawaban. Jawaban subjek atas butir soal dalam tiap kuesioner 
pada uji coba dan penelitian diskor dengan 1 untuk jawaban benar dan 0 untuk jawaban salah.

\section{A. KUESIONER PEMAHAMAN TEKS EKSPOSITORI}

Kuesioner pemahaman teks ekspositori berisi sejumlah butir soal yang bertujuan untuk mengukur pemahaman teks dalam taraf representasi general tentang teks (model situasi). Teks diambil dari surat kabar Kompas dan Media Indonesia edisi bulan Desember 2006, Januari, Februari, Maret, dan April 2007 dengan didasarkan pada kriteria karakteristik teks ekspositori. Contoh kuesioner tipe A dengan gagasan utama di awal teks adalah berikut.

Indonesia Agri Resources Ltd, anak usaha dari PT Indofood Sukses Makmur Tbk, memeroleh dana sebesar Rp 2,4 triliun dari hasil penawaran saham perdananya ke publik. Dana tersebut akan digunakan untuk pengembangan usaha PT Salim Ivomas Pratama, anak usaha Indofood, dalam hal ekspansi perkebunan kelapa sawit, peremajaan dan relokasi pabrik pengolahan minyak goreng, margarin dan lemak nabati, serta keperluan modal kerja.

Gagasan utama teks di atas adalah:

a. Pengembangan usaha PT Salim Ivomas Pratama.

b. Indofood memperluas usaha makanan.

c. Anak usaha Indofood meraih dana triliunan rupiah.

d. Ekspansi dan modal kerja penting untuk meraih laba.

dan kuesioner tipe B yang telah dibuat paralel dengan kuesioner tipe B dengan gagasan utama di akhir teks dapat diamati sebagai berikut.

Indonesia Tani Semesta merencanakan pengembangan usaha PT Argo Inovasi Utama, anak usaha Indoboga, dalam hal ekspansi perkebunan teh, kopi, kelapa, renovasi pabrik pengolahan tepung terigu, margarin dan lemak nabati, serta keperluan modal kerja. Untuk tujuan tersebut, perusahaan yang merupakan anak usaha dari PT Indoboga Prima Rasa Tbk ini memeroleh dana sebesar Rp 4,5 triliun dari hasil penawaran saham perdananya ke publik.

Gagasan utama teks di atas adalah:

a. Pengembangan usaha PT Argo Inovasi Utama.

b. Indoboga memperluas usaha makanan.

c. Anak usaha Indoboga meraih dana triliunan rupiah.

d. Ekspansi dan modal kerja penting untuk meraih laba.

Jawaban yang benar sesuai dengan judul dalam artikel asal adalah anak usaha Indofood meraih dana triliunan rupiah atau yang paralel dengan itu.

\section{B. KUESIONER BERPIKIR DEDUKTIF}

Kuesioner berpikir deduktif berisi sejumlah butir soal yang bertujuan untuk mengukur kemampuan berpikir deduktif siswa. Contoh kuesioner berpikir deduktif perhatikan sebagai berikut. 
Bilangan prima adalah bilangan yang hanya dapat dibagi satu dan oleh dirinya sendiri 3, 5, dan 7 adalah bilangan prima.

Jadi:
a. $\quad 3,5$, dan 7 adalah bilangan ganjil.
b. Bilangan ganjil adalah bilangan prima.
c. $\quad 3,5$, dan 7 hanya dapat dibagi 1 dan dirinya sendiri.
d. 9 adalah bilangan ganjil yang bukan prima.

Jawaban yang benar sesuai dengan hukum dan prinsip silogisme adalah c.

\section{KUESIONER BER PIKIR INDUKTIF}

Kuesioner berpikir induktif berisi sejumlah butir soal yang bertujuan untuk mengukur kemampuan berpikir induktif siswa. Contoh kuesioner berpikir induktif perhatikan sebagai berikut.

\section{Hitler adalah diktator dan bengis \\ Stalin adalah diktator dan bengis \\ Castro adalah diktator \\ Oleh karena itu:}

a. Castro sangat boleh jadi juga bengis.

b. Castro pasti diktator yang bengis.

c. Castro adalah diktator yang otoriter.

d. Castro adalah pemimpin negara komunis.

Jawaban yang benar sesuai dengan dan prinsip silogisme induktif adalah a.

\section{KONTROL PENELITIAN}

Variabel nonpenelitian yang dikontrol adalah jenis kelamin subjek dengan melibatkan siswa laki-laki dan perempuan, latar belakang jurusan sekolah subjek dengan melibatkan siswa IPA dan IPS, minat subjek dengan memberikan teks ekspositori dengan tema bervariasi, seperti isu tentang lingkungan hidup, seni, budaya, aktivitas pelajar dan pemuda, ekonomi, sosial, politik, olah raga, kesehatan, industri. Tingkat kesulitan butir soal dalam kuesioner, dari yang paling mudah ke yang paling sulit dengan cara menghitung proporsi benar-salah jawaban subjek terhadap tiap butir soal pada semua kuesioner pada uji coba. Karakteristik teks ekspositori berdasarkan rujukan yang ada. Karakteristik kuesioner berpikir deduktif dan induktif yang dibuat berdasarkan hukum dan aturannya masing-masing dan konteksnya adalah kehidupan sehari-hari seperti lingkungan sekolah, kecamatan, hiburan, olah raga, pengetahuan umum, politik, ekonomi, sosial, seni, budaya, warna, bentuk, bunga, hewan, dan bentuk matematika. 
SUBJEK

Subjek uji coba alat ukur dan penelitian adalah siswa sekolah menengah atas dengan dasar pemikiran bahwa mereka telah mencapai taraf perkembangan berpikir formal operasional yang karakteristiknya adalah mampu berpikir abstrak, logis, dan hipotetis. Mereka dipilih dengan teknik random bertahap dengan masing-masing subjek memiliki kesempatan untuk dipilih sebagai subjek penelitian (Tilley 1996). Teknik random ini dilakukan terhadap wilayah DKI Jakarta, status sekolah (negeri atau swasta), sekolah, kelas IPA dan IPS. Untuk uji coba alat ukur terpilih 74 siswa kelas II SMAN 47 Jakarta Selatan yang terdiri atas 35 siswa jurusan IPA, dan 39 siswa jurusan IPS; 32 orang siswa laki-laki dan 42 orang siswa perempuan. Untuk penelitian terpilih 91 siswa kelas II SMAN 30 Jakarta Pusat yang terdiri atas 54 siswa jurusan IPA dan 37 siswa jurusan IPS; 32 orang siswa laki-laki dan 59 orang siswa perempuan.

\section{PROSEDUR}

Subjek uji coba menerima semua tipe kuesioner dan diminta untuk memilih salah satu pilihan jawaban yang dianggap paling tepat dari tiap-tiap butir soal dalam waktu yang tersedia. Data uji coba ini kemudian dihitung secara statistik untuk menguji keandalan dan kesahihan butir soal dengan formula statistik/standar kesalahan dari interkorelasi butir rata-rata dalam keseluruhan soal dan analisis butir soal dengan skor total. Butir soal yang memiliki skor korelasi tinggi dan signifikan dengan skor total akan dipilih untuk menjadi butir kuesioner penelitian.

Subjek penelitian menerima semua tipe kuesioner yang sudah direvisi berdasarkan hasil uji coba dan diminta untuk memilih salah satu pilihan jawaban yang dianggap paling tepat dari tiap-tiap butir soal dalam waktu yang tersedia. Data dari penelitian ini kemudian dihitung secara statistik untuk menguji korelasi antarvariabelnya.

\section{METODE PENGOLAHAN DATA}

Dari Robinson (1981), Mendenhall dan Sincich (1996), dan Tilley (1996) didapatkan rumus statistik untuk uji keandalan, kesahihah, distribusi skor dan korelasi. Uji keandalan tiap kuesioner dilakukan dengan menghitung konsistensi internal butir soal atau Alpha Cronbach:

$$
\alpha=\frac{n}{n-1}\left(1-\frac{\sum v_{i}}{v_{t}}\right)
$$

$n=$ banyaknya item; $v_{\mathrm{i}}=$ varian item ke $\mathrm{i} ; v_{\mathrm{t}}=$ varian total dengan kriteria keandalan

Uji kesahihan butir soal tiap kuesioner dengan menghitung korelasi antara skor butir soal dan kriteria atau skor total dengan cara berikut. 


$$
\rho=\frac{\sum_{i=1}^{n} R\left(X_{i}\right) R\left(Y_{i}\right)-n\left(\frac{n+1}{2}\right)^{2}}{\left(\sum_{i=1}^{n} R\left(X_{i}\right)^{2}-n\left(\frac{n+1}{2}\right)^{2}\right)^{1 / 2}\left(\sum_{i=1}^{n} R\left(Y_{i}\right)^{2}-n\left(\frac{n+1}{2}\right)^{2}\right)^{1 / 2}}
$$

$\rho=$ rho, koefisien korelasi

$\mathrm{R}\left(\mathrm{X}_{\mathrm{i}}\right)$ rank dari $\mathrm{X}_{\mathrm{i}} ; \mathrm{X}$ adalah skor pengamatan ke $\mathrm{i}$ dari variabel $\mathrm{X}$ $\mathrm{R}\left(\mathrm{Y}_{\mathrm{i}}\right)$ rank dari $\mathrm{Y}_{\mathrm{i}}$; $\mathrm{Yi}$ adalah skor pengamatan ke i dari variabel $\mathrm{Y}$ $\mathrm{n}=$ banyaknya pengamatan

Normalitas distribusi skor dengan rumus Shapiro-Wilk untuk menentukan teknik penghitungan statistik apa yang akan digunakan seperti berikut.

$$
\begin{aligned}
& \mathrm{T}^{3}=\frac{1}{D}\left[\sum_{i=1}^{k} a_{i}\left(X^{(n-i+1)}-X^{(i)}\right)\right]^{2} \\
& D=\sum_{i=1}^{n}\left(X_{i}-\bar{X}\right)^{2}
\end{aligned}
$$

$D \quad=\quad$ denominator dari statistik uji

$\mathrm{T} \quad=\quad$ statistik uji

$\mathrm{a}_{\mathrm{i}} \quad=\quad$ nilai yang tercantum pada Tabel A17 (koefisien untuk tes Shapiro-Wilk)

$\bar{X} \quad=\quad$ rerata skor $\mathrm{X}$

$X i=$ pengamatan ke $\mathrm{i}$

$X^{(i)}=\quad$ X urutan ke $\mathrm{i}$

Korelasi Pearson dan Spearman untuk menguji korelasi antara variabel penelitian pemahaman teks ekspositori dan kemampuan berpikir deduktif dan induktif dalam formula berikut.

$$
\rho=\frac{\sum_{i=1}^{n} R\left(X_{i}\right) R\left(Y_{i}\right)-n\left(\frac{n+1}{2}\right)^{2}}{\left(\sum_{i=1}^{n} R\left(X_{i}\right)^{2}-n\left(\frac{n+1}{2}\right)^{2}\right)^{1 / 2}\left(\sum_{i=1}^{n} R\left(Y_{i}\right)^{2}-n\left(\frac{n+1}{2}\right)^{2}\right)^{1 / 2}}
$$


$\rho=$ rho, koefisien korelasi

$R\left(X_{i}\right)$ rank dari $X_{i} ; X_{i}$ adalah skor pengamatan ke $i$ dari variabel $X$ $\mathrm{R}\left(\mathrm{Y}_{\mathrm{i}}\right)$ rank dari $\mathrm{Y}_{\mathrm{i}^{\prime}} \mathrm{Yi}$ adalah skor pengamatan ke i dari variabel $\mathrm{Y}$ $\mathrm{n}=$ banyaknya pengamatan

Signifikansi perbedaan rerata dalam populasi dengan formula Kruskal-Wallis seperti berikut

$$
\begin{aligned}
& \mathrm{T}=\frac{1}{S^{2}}\left(\sum_{i=1}^{k} \frac{R_{i}^{2}}{n_{i}}-\frac{N(N+1)^{2}}{4}\right) \\
& \mathrm{N}=\sum_{i=1}^{k} n_{1} ; R=\sum_{i=1}^{n_{i}} R\left(\mathrm{X}_{1 j}\right) \\
& S^{2}=\frac{1}{N-1}\left(\sum_{\text {allrank }} R^{\prime}\left(X_{1 j}\right)^{2}-N \frac{(N+1)^{2}}{4}\right) \\
& \mathrm{R}_{\mathrm{i}}=\text { jumlah rank stiap pengamatan ke } \mathrm{i} \\
& \mathrm{N}=\text { total pengamatan untuk semua sampel }
\end{aligned}
$$

\section{HASIL PENELITIAN DAN ANALISIS}

Dengan taraf signifikansi 0,05, uji korelasi antarvariabel penelitian dengan teknik korelasi Spearman memperlihatkan bahwa pemahaman teks ekspositori secara umum berkorelasi secara signifikan dengan kemampuan berpikir deduktif. Pemahaman teks ekspositori Tipe A dengan gagasan utama di awal teks berkorelasi secara signifikan dengan kemampuan berpikir deduktif. Di sisi lain, tidak ada korelasi signifikan antara berpikir deduktif dan pemahaman teks ekspositori Tipe B dengan gagasan utama di akhir teks, antara kemampuan berpikir induktif dan pemahaman teks ekspositori secara umum, dan dengan gagasan utama baik di awal dan di akhir teks.

\begin{tabular}{|l|c|c|c|c|}
\hline \multicolumn{1}{|c|}{ Pemahaman teks } & \multicolumn{2}{|c|}{ Berpikir deduktif } & \multicolumn{2}{c|}{ Berpikir induktif } \\
\hline \multirow{2}{*}{$\begin{array}{l}\text { Pemahaman teks } \\
\text { ekspositori tipe A }\end{array}$} & Tinggi & Rendah & Tinggi & Rendah \\
\cline { 2 - 5 } & 8,37 & 7,45 & 8,05 & 7,83 \\
\hline $\begin{array}{l}\text { Pemahaman teks } \\
\text { ekspositori tipe B }\end{array}$ & 6,33 & 5,88 & 6,18 & 6,06 \\
\hline
\end{tabular}

Tabel 1. Distribusi rerata skor pemahaman teks ekspositori tipe A dan tipe B pada kelompok berpikir deduktif dan induktif 


\begin{tabular}{|l|l|l|l|}
\hline \multicolumn{1}{|c|}{ Variabel } & \multicolumn{1}{|c|}{ Spearman's rho } & \multicolumn{1}{c|}{$\begin{array}{c}\text { Berpikir } \\
\text { deduktif }\end{array}$} & \multicolumn{1}{|c|}{$\begin{array}{c}\text { Berpikir } \\
\text { induktif }\end{array}$} \\
\hline \multirow{4}{*}{ Pemahaman teks umum } & Correlation Coef. & 0,255 & 0,033 \\
\cline { 2 - 4 } & Sig. (2-tailed) & $0,015^{*}$ & 0,757 \\
\cline { 2 - 4 } & $\mathrm{N}$ & 91 & 91 \\
\hline \multirow{2}{*}{$\begin{array}{l}\text { Pemahaman } \\
\text { teks tipe A }\end{array}$} & Correlation Coef. & 0,315 & 0,025 \\
\cline { 2 - 4 } & Sig. (2-tailed) & $0,002^{*}$ & 0,812 \\
\cline { 2 - 4 } & $\mathrm{N}$ & 91 & 91 \\
\hline \multirow{3}{*}{$\begin{array}{l}\text { Pemahaman } \\
\text { teks tipe B }\end{array}$} & Correlation Coef. & 0,166 & 0,042 \\
\cline { 2 - 4 } & Sig. (2-tailed) & 0,115 & 0,689 \\
\cline { 2 - 4 } & $\mathrm{N}$ & 91 & 91 \\
\hline
\end{tabular}

*) taraf signifikansi 0,05

Tabel 2. Hasil uji korelasi antara pemahaman teks ekspositori dan berpikir deduktif dan induktif

Untuk variabel individual nonpenelitian jenis kelamin, uji signifikansi terhadap perbedaan rerata siswa laki-laki dan perempuan dengan teknik statistik tes Kruskal-Wallis diperoleh hasil bahwa ada perbedaan signifikan antara kedua kelompok itu dalam kemampuan berpikir induktif dengan rerata siswa perempuan lebih tinggi daripada rerata siswa laki-laki. Sementara itu, dalam pemahaman teks ekspositori dengan gagasan utama di awal dan di akhir teks tidak ada perbedaan rerata yang signifikan antara kedua kelompok itu.

\begin{tabular}{|l|l|l|l|}
\hline \multicolumn{1}{|c|}{ Variabel } & \multicolumn{1}{c|}{ Laki-laki } & \multicolumn{1}{c|}{ Perempuan } & \multicolumn{1}{c|}{ Total } \\
\hline Pemahaman teks umum & 14,4 & 13,9 & 14,15 \\
\hline Pemahaman teks A & 8,06 & 7,92 & 7,97 \\
\hline Pemahaman teks B & 6,38 & 6,00 & 6,13 \\
\hline Berpikir deduktif & 11,91 & 13,56 & 12,98 \\
\hline Berpikir induktif & 15,31 & 21,39 & 19,25 \\
\hline Total N & 32 & 59 & 91 \\
\hline
\end{tabular}

Tabel 3. Rerata skor pemahaman teks ekspositori tipe A, tipe B, berpikir deduktif dan berpikir induktif pada siswa laki-laki dan siswa perempuan. 


\begin{tabular}{|l|l|l|l|l|}
\hline \multicolumn{1}{|c|}{ Statistik } & \multicolumn{1}{|c|}{$\begin{array}{c}\text { Pemahaman } \\
\text { teks a }\end{array}$} & \multicolumn{1}{|c|}{$\begin{array}{c}\text { Pemahaman } \\
\text { teks b }\end{array}$} & \multicolumn{1}{|c|}{$\begin{array}{c}\text { Berpikir } \\
\text { deduktif }\end{array}$} & \multicolumn{1}{|c|}{$\begin{array}{c}\text { Berpikir } \\
\text { induktif }\end{array}$} \\
\hline Chi-Square & 0,024 & 0,526 & 3,010 & 11,985 \\
\hline Df & 1 & 1 & 1 & 1 \\
\hline Asymp.Sig & 0,877 & 0,468 & 0,083 & $0,001^{*}$ \\
\hline
\end{tabular}

* taraf signifikansi 0,05

Tabel 4. Hasil uji signifikansi perbedaan rerata pemahaman teks ekspositori tipe A, pemahaman teks ekspositori tipe B, berpikir deduktif dan berpikir induktif pada siswa laki-laki dan perempuan.

Untuk variabel individual nonpenelitian jurusan sekolah IPA dan IPS, uji signifikansi terhadap perbedaan rerata siswa jurusan IPA dan jurusan IPS dengan teknik statistik tes Kruskal-Wallis diperoleh hasil bahwa ada perbedaan signifikan antara rerata kedua kelompok tersebut dalam pemahaman teks ekspositori dengan gagasan utama di awal teks, di akhir teks dan kemampuan berpikir deduktif, dengan rerata siswa jurusan IPA lebih tinggi daripada siswa jurusan IPS; sedangkan dalam kemampuan berpikir induktif, kedua kelompok tidak berbeda secara signifikan.

\begin{tabular}{|l|l|l|l|}
\hline \multicolumn{1}{|c|}{ Variabel } & \multicolumn{1}{c|}{ IPA } & \multicolumn{1}{c|}{ IPS } & \multicolumn{1}{c|}{ Total } \\
\hline Pemahaman teks umum & 15,6 & 11,9 & 13,7 \\
\hline Pemahaman teks A & 8,87 & 6,65 & 7,97 \\
\hline Pemahaman teks B & 6,76 & 5,22 & 6,13 \\
\hline Berpikir deduktif & 14,41 & 10,89 & 12,98 \\
\hline Berpikir induktif & 20,28 & 17,76 & 19,25 \\
\hline Total N & 54 & 37 & 91 \\
\hline
\end{tabular}

Tabel 5. Rerata skor pemahaman teks ekspositori tipe A, pemahaman teks ekspositori tipe B, berpikir deduktif dan berpikir induktif pada siswa jurusan IPA dan IPS

\begin{tabular}{|l|l|l|l|l|}
\hline \multicolumn{1}{|c|}{ Statistik } & \multicolumn{1}{|c|}{$\begin{array}{c}\text { Pemahaman } \\
\text { teks A }\end{array}$} & \multicolumn{1}{|c|}{$\begin{array}{c}\text { Pemahaman } \\
\text { teks B }\end{array}$} & \multicolumn{1}{|c|}{$\begin{array}{c}\text { Berpikir } \\
\text { deduktif }\end{array}$} & \multicolumn{1}{|c|}{$\begin{array}{c}\text { Berpikir } \\
\text { induktif }\end{array}$} \\
\hline Chi-Square & 15,995 & 7,571 & 20,056 & 3,018 \\
\hline Df & 1 & 1 & 1 & 1 \\
\hline Asymp. Sig & $0,000^{*}$ & $0,006^{*}$ & $0,000^{*}$ & 0,082 \\
\hline
\end{tabular}

* taraf signifikansi 0,05

Tabel 6. Hasil uji signifikansi perbedaan rerata pemahaman teks ekspositori tipe A, tipe B, berpikir deduktif dan berpikir induktif pada siswa jurusan IPA dan IPS

\section{SIMPULAN DAN DISKUSI}

Secara umum pemahaman teks ekspositori berkorelasi dengan kemampuan berpikir deduktif dan tidak berkorelasi dengan kemampuan berpikir 
induktif. Sesuai dengan tingkatan pemahaman yang dikemukakan Kintsch dalam Construction Integration (Solso 1991; Stevenson 1993; Jay 2003), maka pemahaman teks ekspositori yang berkorelasi dengan berpikir deduktif ini ada pada tingkatan yang paling tinggi yang diwujudkan dalam bentuk kemampuan menghasilkan struktur makro atau intisari teks yang menunjukkan pemahaman atas keseluruhan makna yang ada pada teks. Dengan kata lain, mampu dengan baik mengidentifikasikan gagasan utama teks merupakan indikasi yang jelas bahwa subjek telah membentuk representasi mental yang koheren tentang teks tersebut, yang didukung oleh kemampuan menalar secara logis. Kemampuan subjek dalam berpikir deduktif, yang ditandai oleh kemampuan menarik simpulan logis dari informasi yang tersedia, mendukung proses pemahaman teks ekspositori dalam tingkatan abstraksi dalam bentuk kemampuan mengidentifikasi gagasan utama yang menggambarkan keseluruhan makna teks. Hasil ini sejalan dengan apa yang dikemukakan oleh Eysenck (1994) dan Thompson (2000), bahwa penalaran adalah proses yang bersandar pada aturan dalam menarik konklusi terhadap sejumlah fakta, bukti, dan data, disertai evaluasi terhadapnya. Kemampuan berpikir deduktif menunjukkan berapa jauh pembaca mampu menganalisis, mengaitkan sejumlah elemen, menalar secara logis atau menarik simpulan dari argumen atau pernyataan yang tersedia dalam teks, yang selanjutnya membangun representasi mental tentang makna dan situasi yang ada dalam teks.

Letak gagasan utama pada teks juga menghasilkan tingkat korelasi yang berbeda, yaitu pemahaman teks ekspositori tipe A dengan gagasan utama terletak pada awal teks berkorelasi signifikan dengan kemampuan berpikir deduktif. Artinya, kemampuan berpikir deduktif berperan dalam proses pemahaman teks ekspositori dengan gagasan utama di awal teks. Hal ini sejalan dengan penelitian yang dilakukan oleh Van den Broek et al. (2003) tentang pemahaman gagasan utama teks naratif di mana letak gagasan utama di awal teks lebih dipahami sebagai gagasan utama teks daripada bila terletak di bagian akhir teks. Sangat boleh jadi hal ini berkaitan dengan proses kognitif lain, yaitu persepsi, perhatian dan ingatan yang lebih tertuju pada apa yang ada di awal teks, sehingga ia ditangkap dan disimpan dalam ingatan pembaca. Selain itu, struktur teks yang seperti piramida terbalik dengan gagasan utama di awal teks yang berisi informasi yang luas dan kemudian semakin mengerucut, yang berisi informasi yang lebih rinci, sejalan dengan konsepsi umum berpikir deduktif yang bergerak dari keadaan umum ke keadaan spesifik, atau dari konsepsi abstrak ke konsepsi kongkret.

Dari sisi lain, adanya hubungan antara pemahaman teks dan berpikir deduktif juga menunjukkan hubungan yang signifikan antara linguistik dan pikiran. Proses psikologis yang berlangsung di balik pemahaman teks ekspositori adalah kemampuan dalam menyarikan hubungan logis di antara elemen dalam teks dan menggunakannya untuk membangun representasi struktur logis teks. Artinya, untuk sampai pada tingkatan ini, proses kognitif yang lebih tinggi berperan di dalamnya yang melibatkan proses abstraksi 
dan pembentukan hipotesis dalam bentuk representasi mental yang bersifat simbolis tentang makna. Pemahaman teks dalam tingkatan ini terukur melalui representasi makna yang terbentuk dari situasi yang ada pada teks.

Dalam kaitannya dengan kemampuan berpikir induktif, tidak ditemukan korelasi yang signifikan antara berpikir induktif dengan pemahaman teks ekspositori secara umum, juga dengan lokasi gagasan utama, di awal atau di akhir. Hal ini diasumsikan sejalan dengan teori yang menyatakan bahwa berpikir induktif lebih didasari oleh probabilitas dan generalisasi dari informasi yang tersedia, dan bukan melibatkan logika yang memungkinkan penarikan konklusi secara logis berdasarkan premis yang ada. Atau dengan kata lain, subjek memahami dan menangkap gagasan utama teks tidak didasari oleh penarikan simpulan dari premis atau pernyataan yang tersedia dalam teks.

Terkait dengan gender, kemampuan berpikir induktif perempuan lebih tinggi dari kemampuan berpikir induktif laki-laki. Hal ini sejalan dengan apa yang dikemukakan oleh Zago et al. (2007) dan Schaie (2007) yang menjelaskan bahwa perempuan tampil lebih baik dalam tugas verbal, ingatan, kefasihan dalam kata, dan penalaran induktif daripada laki-laki. Sementara itu, tidak ada perbedaan yang signifikan antara laki-laki dan perempuan dalam pemahaman teks ekspositori dengan gagasan utama di awal teks, di akhir teks, serta dalam berpikir deduktif. Hal ini sesuai dengan hasil penelitian Brandon (1989) yang mengemukakan bahwa tidak ada perbedaan dalam kemampuan penalaran deduktif pada laki-laki dan perempuan. Dengan kata lain, laki-laki dan perempuan berpikir sama logis dalam merespons teks yang dibacanya sehingga memahami teks ekspositori dalam cara yang sama. Laki-laki dan perempuan tidak berbeda dalam berpikir yang sifatnya top-down atau dari luas ke spesifik; sementara perempuan lebih baik dalam berpikir bottom-up atau dari spesifik ke luas.

Selanjutnya, terkait dengan latar belakang jurusan sekolah, kelompok siswa jurusan IPA secara signifikan lebih tinggi daripada kelompok siswa jurusan IPS dalam hal pemahaman teks ekspositori dengan gagasan utama di awal teks, dengan gagasan utama di akhir teks, dan kemampuan berpikir deduktif. Dari hasil penelitian ini tampak bahwa latar belakang jurusan IPA berperan dalam pemahaman teks ekspositori umum, pemahaman teks ekspositori dengan gagasan utama di awal teks, di akhir teks, dan berpikir deduktif. Sangat boleh jadi hal ini disebabkan oleh proses belajar dan pengalaman yang mengondisi cara mereka berpikir dan memahami teks ekspositori. Dalam kegiatan belajar sehari-hari, mereka lebih banyak mendapatkan mata pelajaran matematika dan ilmu pengetahuan alam yang lebih terkait dengan logika daripada kelompok dengan latar belakang jurusan IPS.

\section{SARAN}

Dengan hasil yang didapatkan dari penelitian ini, kajian selanjutnya yang lebih mendalam dapat dilakukan berkaitan dengan variabel, instrumen, dan subjek penelitian untuk memperkaya khazanah psikolinguistik. Kajian tentang 
kemampuan berpikir deduktif dan berpikir induktif dalam pemahaman teks dapat juga melibatkan genre teks lain, seperti teks naratif, misalnya. Sebagaimana telah dijelaskan dalam bab terdahulu mengenai teori tentang teks, teks ekspositori dan teks naratif berbeda karakter, struktur dan isi sehingga peran keterlibatan berpikir deduktif dan berpikir induktif dalam memahami kedua genre teks tersebut dapat lebih diteliti dengan tajam.

Berkaitan dengan instrumen penelitian, kuesioner pemahaman teks ekspositori dapat lebih dikembangkan untuk mengukur variabel pemahaman teks dalam tiga tingkatan pemahaman yang berbeda, struktur permukaan, proposisi, dan struktur makro atau intisari teks, tidak hanya dengan kuesioner pilihan ganda, tetapi dengan bentuk kuesioner lain, seperti menceritakan kembali isi teks dalam kata-kata sendiri. Begitu juga dengan instrumen untuk mengukur kemampuan berpikir deduktif dan berpikir induktif dapat lebih dikembangkan dan diujicobakan beberapa kali untuk memeroleh konsistensi dan kesahihan pengukuran yang lebih akurat. Dengan demikian, profil aspek dan proses kognitif dalam pemahaman teks dapat disusun dengan lebih komprehensif.

Selanjutnya, untuk hasil yang lebih dapat digeneralisasikan, penelitian tentang pemahaman teks eskpositori, berpikir deduktif dan berpikir induktif dapat dikembangkan dengan melibatkan banyak siswa dari berbagai sekolah dan latar belakang jurusan, latar belakang sosial ekonomi yang lebih bervariatif, dan melibatkan faktor individual lain seperti, jenis kelamin, motivasi, konsep diri atau tingkat aspirasi pembaca. Di samping itu, aspek individual lain, seperti pengaruh latar belakang pengetahuan subjek, dapat menjadi fokus kajian yang lebih mendalam pada studi tentang pemahaman teks ini.

\section{DAFTAR PUSTAKA}

Bluedorn, Harvey. 1995. "Two methods of reasoning", (www.triviumpursuit. com/articles/two_methods_of_reasoning.php), diakses 24 Desember 2006.

Brandon, E.P. 1989. "Gender and competence in deductive Logic", (http:// cavehill.uwi.edu/bnccde/epb/GENELOG.html), diakses 24 Desember 2006.

Copi, Irving M. dan Keith Burgess-Jackson.1996. Informal logic. New Jersey: Simon and Schuster. (Edisi pertama: 1982).

Eysenck, Michael W. 1994. The Blackwell dictionary of cognitive psychology. Massachusetts: Blackwell Publishers. (Cetakan pertama tahun 1990).

Falmagne, Rachel Joffe dan Joanna Gonsalves. 1995. "Deductive inference", Annual Review of Psychology 46: 525-559. Dikutip dari (www.questia.com), diakses 17 Mei 2006.

Grabe, William dan Fredricka L. Stoller. 2002. Teaching and researching reading. Harlow: Pearson Education Limited.

Hayon, Y.P. 2005. Logika: prinsip-prinsip bernalar tepat, lurus, dan teratur. Jakarta: ISTN.

Hurley, Patrick J. 2000. A concise introduction to logic. Edisi ketujuh. Belmont: Wadsworth/Thomas Learning. (Edisi pertama tahun 1982). 
Hughes, Arthur. 1990. Testing for language teachers. Glasgow: Bell and Bain. Jay, Timothy B. 2003. The psychology of language. London: Pearson Education.

Just, Marcel Adam dan Patricia A. Carpenter. 1987. The psychology of reading and language comprehension. Newton: Allyn and Bacon.

Kline, Paul. 1986. A handbook of test construction: introduction to psychometric design. London: Methuen.

Lobner, Sebastian. 2002. Understanding semantics. London: Arnold.

McShane, John. 1991. Cognitive development: an information processing approach. Oxford: Basil Blackwell.

Mendenhall, William dan Terry Sincich. 1996. A second course in statistics: regression analysis. Edisi kelima. New Jersey: Prentice Hall International.

Richter, Tobias dan Johannes Naumann. "Computer-based assessment of reading Skills", (http:psydok.sulb.unisaarland.de/volltexte/2004/317/pdf/ Richter_Naumann_2000.pdf.), diakses 17 June 2006.

Robinson, Paul W. 1981 Fundamentals of experiment psychology. Edisi kedua. New Jersey: Prentice Hall. (Edisi pertama: 1976).

Schaie, K. Warner. 2007. "Development influences on adult intelligence: the seattle longitudinal study", (http://books.google.com/books), diakses 1 Mei 2007.

Singer, Murray dan Gordon O'Connell. 2006. “Robust inference process in the comprehension of expository text", European Journal of Cognitive Psychology 15: 607-631. Dikutip dari (www.umanitoba.ca/ faculties / arts / psychology/documents/s_and_oconnl.pdf), diakses 15 Mei 2006.

Singer, Murray dan Gilbert Remillard. 2004. "Retrieving text inferences: controlled and automatic influences", Memory and Cognition 32/8: 12231237.

Solso, Robert L. 1991. Cognitive psychology. Edisi ketiga. Boston: Allyn and Bacon.

Stevenson, Rosemary J. 1993. Language, thought, and representation. West Sussex: John Wiley and Sons.

Thomson, Anne. 2000. Critical reasoning: a practical introduction. London: Routledge.

Tilley, Andrew. 1996. An introduction to psychologycal research and statistics. Edisi ketiga. St. Lucia: Pineapple Press.

Van den Broek, Paul, Julie S. Lynch, Jan Naslund, Carolyn E. Ievers-Landis, dan Kees Verduin. 2003. “The development of comprehension of main ideas in narratives: evidence from the selection of titles", Journal of Educational Psychology 95/4: 707-718.

Weir, Cyril. 1993. Understanding and developing language test. London: Prentice Hall

Zago, L., S. Moutier; S. Rossi, V. Beaucousin, F. Andersson, L. Petit, O. Houde, dan N. Tzourio-Mazoyer. 2007. "Neural Correlates of Syllogistic Reasoning: A Gender Effect?". (Http://gin.cyceron.fr/document.php?project), diakses 2 Februari 2007. 